opens to view by looking over the verge of this crater down into the precipitous abyss. The crater, with its bottom covered with snow and the sides all whitened with a glacial crust, suggests to the beholder a gigantic cauldron hollowed out in marble. Enormous rocks, which have tumbled down from the brim of the crater, look like minute black specks against the whiteness of the bottom. The composition of the lava is practically entirely basaltic; but reddish rocks of trachyte are strewn about the circumference of the original crater, which shows that sometimes trachytic eruptions have taken place here, as in Askja in I875. When the weather cleared, I had distinctly in view the greater part of Odáðahraun as well as Dyngjufjöll proper, and all the lava currents which have taken their course from the latter complex of volcanoes. In a north-westerly direction from the above-described volcano is another, lower, but quite as wide in circumference, to which we gave the name of Kerlingar-Dyngja. Having surveyed Dyngja, we returned the same way we had come, and reached our tent at half-past two o'clock the next morning.

In a southerly direction from Heroubrei there extends a very considerable mountain range, 3400 feet high, which is called Tögl (Tails) ; it is separated from Herðubrei $r$ by a narrow gate through which, once upon a time, a lava current has found its way. Thus Herðubreir is surrounded by lava on all sides, though that mountain itself is no volcano, but a pile of coarse palagonite breccia interspersed with stray thin layers of basalt throughout its lower parts. One of my excursions I directed to the Tögl. From the tops of these mountains an extensive view opens southward over the sands along the course of Jökulsá and the northern region of Vatnajökull. The aspect of the country to the south of Herðubreid is truly forbidding, all covered with the yellow-gray scoriz from the explosion of Askja in 1875, generally one to two feet in thickness, and no sign anywhere of vegetation. The whole southern horizon exhibits the vast expanse of the snow-white glacial bolsters of Vatnajökull, out of which, in a northerly direction, rises the enormous complex of volcanoes called Kverkfjöll. In some fiery convulsion this mass of mountains has split from end to end, and through the rent a glacier has found its way right down to the level land below. To the west of this rent I observed in the jökull a mass of craters, from one of which huge clouds of white steam ascended into the air. Nothing is known about the volcanic activity in this spot, no one having ever visited those parts of Vatnajökull. On the western side of Kverkfjöll the jökull is one flat ice plateau all the way down to Odádahraun, skirting into a number of moving glaciers terminating in sands and extensive moraines, from which flow innumerable affluents to Jökulsá in Axarfjörd. Towards the east, about the approaches to Sandfell, the next highest mountain in Iceland ( 5800 feet), the jökull exhibits sharp-cut black vertical walls, probably ledges of underlying basaltic belts; but further to the west the flatness of the jökull owes its formation to the substratum bcing made up of palagonite tufa, a softer and more easily ground material. Our western view was determined by a part of Ódádahraun, southern Dyngjufjöll, Askja, and the southern parts of Herðubreiðarfjöll. At the southern termination of Dyngja there rises a very peculiarly formed tufa "fcll," along the crest of which is to be observed a row of a number of vertical tufa peaks, each from one to two hundred feet high, so that the outline of the mountain gives the impression of a gigantic hedgehog.

Next day I set out on the examination of Herdubreiðarfjöll. Directing our course to the north-east, we ascended on our way a mountain by the banks of Jökulsá called Ferjufjall, near which, as the story goes, there was a ferry in those olden times, when the bishops were in the habit of taking that road over the northern skirts of ódázahraun, to which I have alluded already. In a north- westerly direction from this place excessively ancient lavas come to view, which are clearly older even than the Glacial period, exhibiting everywhere large and unmistakable signs of glacial abrasions. In this excursion we came upon a row of those beacons which by general custom in Iceland are erected to point out where roads run through wildernesses. Most of these beacons were but cumuli of stones; one, however, we found still standing, covered with moss and lichens. This we knew now must be the eastern end of the long-lost road, an assumption which subsequent discovery corroborated. As we approached nearer to Herðubreiðarfjöll we came upon a series of craters surrounded by a recent lava, and so rough that no horse might cross it, almost impassable even for a traveller on foot. Leaving our ponies behind, we made our way across this lava, however, as best we could, and reached the highest crest of the mountains shortly before sunset, and enjoyed from it an extensive view. All about these mountains, which are composed of palagonite breccia, there is a number of ridges observable, with small dales and narrow dips scooped out between them, all, however, totally barren of vegetation. About the central portion this range sinks down into low necks honeycombed with many large craters, from which floods of lava have spread over the surrounding country on both sides, east and west, covering an area of some tens of square miles. Having completed my survey of this region, we returned and joined our ponies shortly after midnight, all scratched and lacerated from the lava, with our shoes and stockings in shreds.

Reykjahlíy, near Mývatn, August 4

TH. THORODDSEN

(To be continued.)

\section{THE CONNECTION BETWEEN CHINESE} MUSIC, WEIGHTS, AND MEASURES

CHINESE music can now be heard by all who desire to hear it at the Health Exhibition, and more may be learned on the subject from the pamphlet published by the Commissioners for the Chinese department. A curious account of the common origin of Chinese weights, measures, and musical notes is contained in a paper read some years ago before the German Asiatic Society of Japan by Dr. Wagener. The story is based on native legends, and is also to be found among the Jesuit "Mémoires concernant les Chinois." Dr. Wagener says there is not the slightest doubt that the Chinese system of weights and measures is more than 4600 years old; and it is a highly remarkable circumstance that, quite irrespective of the fact that it is more scientific and exact, it possesses all the advantages for which the French metrical system is so much praised. In the first place, it starts from a basis supplied by Nature; secondly, the decimal arrangement is almost consistently employed throughout; thirdly, linear and dry measure proceed directly from the same unit as the measure of weight; and lastly, what the metrical system does not do, it regulates in the simplest manner the relations of musical notes, which latter form the starting-point for the whole system of weights and measures. The following account of the origin of this system (says Dr. Wagener) contains fact and fancy mingled, but it is easy to distinguish between them. In the reign of the Emperor Hoang-ti, who ruled over China in the twenty-seventh century before Christ, the scholar Lyng-lun was commissioned to complete the musical system which had been discovered 250 years earlier, and particularly to lay down fixed rules for making musical instruments. Naturally he bad to commence with the bamboo, which had already been long used to give the note for other instruments. He therefore betook himself to the province of Siyung in NorthWestern China, where, on the northern slope of a range of 
high mountains, a species of bamboo grew, which, on account of its uniformity and its structure, being neither too hard nor too soft, was exceedingly suitable for a wind instrument. He cut one down and tried it. Tradition says that it gave the same note as his own voice when he was excited by no emotion; and the rippling of the sources of the great Hoang-ho, or Yellow River, which were in the vicinity, followed in the same tone. At the same time the fabulous bird Fung-Hiang, accompanied by his mate, flew to the place. Both perched themselves on a neighbouring branch, and commenced a song, in the course of which each of the birds gave six separate notes. These are the notes which are called the six male and six female tones in the scale discovered by Lyng-lun, and which correspond to the ancient doctrine of the male and female principles in Nature. As a matter of course, the deepest of the male notes was the one already discovered by the philosopher himself. He now endeavoured to reproduce the other notes with the help of bamboo pipes, and succeeded. His lask was now to lay down fixed rules as to the length of the pipes, so that thenceforth they could be easily constructed everywhere. For this reason, and also because such a scale of notes depends upon slight differences of length, and there were scarcely at this time instruments to divide great lengths, he necessarily arrived at the notion of passing from the less to the greater, and of laying down an adequately small natural unit for his measurements. That could be nothing else but a grain of seed; and now the point was to get seeds of the greatest possible uniformity. He chose a sort of millet, the Sorghum rubrum, the seed of which is of a dark brown colour, and which is said to possess the advantages of greater hardness and uniformity than that of the gray and other kinds. The seed is pointed at the ends, and from one point to the other the length is somewhat greater than in the direction at right angles. Lynglun now fixed the length of the pipe, which gave the keynote at 8I grains of the seed placed lengthwise in a row. But when the grains were placed breadthwise it took 100 grains to give the same length. Thus the double division of $9 \times 9$ and $10 \times$ io was naturally arrived at. According to the dimension in question, it was called a musical or an ordinary foot, the latter being introduced with the decimal subdivision as a measure of length. The breadth of a grain of seed was I fen (a line), ro fen = I tsun (an inch), io tsun = I che (a foot), Io che $=$ I chang, Io chang $=1$ ny. In subsequ nt times the line was divided into tenths, hundredths, \&c. Lyng-lun also laid down rules for the breadth as well as for the length of the pipe, because, although the note is essentially dependent on the length, it is nevertheless necessary for its purity that the pipe should be neither too broad nor too narrow. He therefore fixed the circumference on the inside at nine grains laid lengthwise. With these dimensions, namely, a length of eighty-one grains, and an internal circumference of nine, the pipe which gives the keynote contains just $\mathrm{I} 200$ grains, and this volume accordingly was made the unit of dry measure, and was called a $10 ; 2$ yo $=$ I ko, I ko= I cheng, Io cheng = I ten, io ten $=\mathrm{I} h u$. So far we see how the units of length and dry measure were connected with the musical keynote. The twelve notes of the scale are all derived from the keynote, and are to a certain extent comprehended in it. Hence if the 1200 grains contained in the pipe are divided among the twelve notes it gives to each a hundred, and the weight of these hundred grains was made by Lyng-lun the unit of weight. This was divided and subdivided on the decimal system until a single grain became the lowest weight of all. At a later period even the coinage became connected with this system, for one of the weights, the leang, corresponding to our ounce, became the weight of metal put into a coin, so that the modern tael, in which mercantile quotations are found every day in the Times, is merely an ounce of silver, and is thus directly con- nected with the musical scale. Finally, says Dr. Wagener, it appears from this account that, in China, weights, measures, coinage, and the tuning of musical instruments have been derived quite consistently from a constant unit supplied by Nature herself, and that the essentials of this system are over 4600 years old.

\section{NOTES}

THE Queen has been pleased, through His Grace the Duke of Richmond and Gordon, to intimate a subscription of $25 l$. to the Scottish Marine Station for Scientific Research, Granton, Edinburgh.

The Washington International Prime Meridian Conference discussed at length on Monday a resolution for adopting the Greenwich meridian, which several American and British delegates advocated. M. Janssen, the French delegate, opposed the motion in a long address, arguing in favour of what he called a "ncutral" meridian, and suggesting that the prime meridian should run, either through Behring Straits, or one of the Azores. After some further debate the Conference adjourned subject to the call of the chairman. No opposition to the election of Greenwich was shown excepting by France, but doubts are expressed as to whether the Conference will have any result.

AcCording to the Standard's Calcutta Correspondent, the Commission under the direction of Dr. Klein, appointed by the Indian Government to examine into the cholera question, is satisfied that Dr. Koch's microbe is no the cause of the disease. The Commission is still continuing its inquiries, but so confident is Dr. Klein on the microbe question that he swallowed a number of them without any evil results.

"THE Philadelphia meeting of the American Association," Science states, "is credited with being the most successful up to this time. The total attendance was I 249. Great Britain contributed 303; Pennsylvania, 246; New York, 16r ; Massachusetts, 87; I)istrict of Columbia, 84 ; New Jersey, $5^{8}$; Ohio, 57 ; Connecticut, 32 ; and Virginia, 22. The membership was increased nearly 25 per cent., 515 new members being elected, the number of members up to this meeting being 2033. The number of papers read was larger than ever before, and it is to be hoped that the weeding-out of the trivial matters so often offered was carried to a greater extent than usual. There was a general feeling that there was too much going on. A large portion of the physicists were engaged as examiners at the Electrical Exhihition, and were, of course, interested in the meetings of the Electrical Conference. Somewhat less science, and somewhat more time to enjoy the junlseting, would be more in accordance with the desires of many, if onc may judge from the opinions expressed on the way home. A proposition to confine the reading of papers to the mornings would have met with many supporters."

IT would seem that the International Scientific Association, which it was proposed at Philadelphia to organise, has been really founder. Science informs us that it has now a more assured existence, thanks to the fund of twenty thousand dollars which will be established through the liberality of Mrs. Elizabeth 'l hompson. Of this fund five thousand dollars have already been paid to the Association, and five thousand more will be paid next year on condition of ten thousand being raised from other sources. The income from this fund is to be devoted to research. Not only did Mrs. Thompson give liberally to this new Society, but she also gave one thousand dollars to the American Association for the Advancement of Science, to be used in researches on light and heat. Mrs. Thompson takes great interest in the recent marvellous advances in the application of electricity, and felt a desire to contribute, as far as lay in 